\title{
Psychometric Properties of the Job Related Skills Inventory in Malaysia
} Context

\author{
Chua Bee Seok ${ }^{1}$ \\ University Malaysia Sabah, Faculty Of Psychology \& Education ${ }^{1}$ \\ (Chuabs@Ums.Edu.My) \\ Getrude C. Ah Gang ${ }^{2}$ \\ University Malaysia Sabah, Faculty Of Psychology \& Education ${ }^{2}$ \\ Shazia Iqbal Hashmi ${ }^{3}$ \\ University Malaysia Sabah, Faculty Of Psychology \& Education ${ }^{3}$ \\ Norhamidah Binti Jarimal ${ }^{4}$ \\ University Malaysia Sabah, Faculty Of Psychology \& Education ${ }^{4}$ \\ Agnis Sombuling ${ }^{5}$ \\ University Malaysia Sabah, Faculty Of Psychology \& Education ${ }^{5}$
}

\begin{abstract}
:
The objectives of the current study were to test the internal consistency, convergent and discriminant validity and item analysis of the Job-Related Skills Inventory in the Malaysian context. The study was conducted among 102 employers from the various government departments in Sabah, Malaysia. Cronbach alphas calculated to assess the inventory internal consistency of the inventory. The evidence for convergent validity of the inventory was tested by examining the inter-correlation between sub-aspect of the skills and correlation between the sub-aspects and the four dimensions of Industrial Revolution job-related skill. The discriminant validity of the Inventory was determined by examining the correlation between the inventory score and the scores of the Short Social Desirability Scale. Item analysis was also conducted to test the suitability and gaugeable of the Job-Related Skills Inventory items in the Malaysian context. The scale demonstrated good internal consistency (Cronbach alpha ranged from 0.87 to 0.95 ). The result reported The Job-Related Skills Inventory convergent and discriminant validity was confirmed with the strong relationship among the Inventory dimensions and strong relationship with the four dimensions of Industrial Revolution job-related skill as compared to weak and negative correlation coefficients between the inventory and the Social Desirability Scale. The result of item analysis also indicated all the items were good and suitable to use in the Malaysian context.
\end{abstract}

Keywords: The Goldsmith's Soft Skills Inventory, Reliability, Convergent Validity, Discriminant Validity, Item,Analysis,Malaysian,Context.

\section{I.Introduction:}

Many efforts have been taken by the authorities such as governmental and non-governmental agencies to tackle the unemployability issues among graduates. To obtain a better job in today's competitive world is a dream of all graduates; however, the increasing rate of the unemployability among graduates has raised major global concerns, particularly among graduates and employers. Most graduates showed their concern in shifting from the Education world to world of work ${ }^{[1]}$. On the flip
Side, employers showed great worry with the lack of competency among university fresh graduates that required by the industry ${ }^{[2]}$. Globally, over 70 million youth are unemployed, and 156 million young workers are living in poverty ${ }^{[3]}$. This has also affected Malaysia that the unemployment rate in Malaysia has increased from $3.2 \%$ in 2007 to $3.7 \%$ in 2009. In 2020, Malaysia's unemployment rate is seen at $3.3 \%$ similar to the estimated figure in 2019 according to the Ministry of Finance's Economic 
Outlook 2020 report $^{[4]}$. Malaysia reached its lowest level of unemployment in 2014, with a rate of 2.85 percent ${ }^{[5]}$.There are various factors revealed that contribute to the graduates' unemployability. One of the factors is lack of job-related skills ${ }^{[6]}$. Employers in the industry left negative comments about how graduates lack the suitable skills and qualifications to meet industry needs, particularly communication and problem-solving skills ${ }^{[7]}$. Soft skills are critical to young people's success in the workplace and their development in all domains of life. However, soft skills are poorly understood, not well assessed, and all too often overlooked in policy and institutional contexts, including education, training and the workplace ${ }^{[8]}$.Better understanding of the substantive issues such as unemployability due to lack of skills requires improved measurement tools. By understanding and highlighting the importance of soft skills, may assist young people to acquire the job-related skills for employment and life success [3]. In order to be successful and contribute to the growth of emerging economies, graduates' skills need to be adaptable to both the changing nature of work and the various opportunities that become available to them [3]. Therefore, in designing and implementing training programs with aim to enhance graduates' jobrelated skills, information from various sources such as from graduates, university, employers and the society are needed because they might have different perceptions in identifying which jobrelated skills may lead to employability. In this study, we focused on employers' view to understand the employability issues by using the job-related skills scale that was adopted from different relevant scales. Data from the employers currently provides 30 percent of employment opportunities ${ }^{[5]}$. In searching for the relevant data from the employers, one thing that needs to be taken into account is the instrument that suits with the local context. Many researchers created job-related skills that may help them to capture and understand the employability issues from the employers' perspectives. Employers are increasingly looking for youth who are flexible, adaptable, proactive, creative and collaborative. In short, youth need soft skills: the broad set of skills, attitudes, behaviours and personal qualities that enable them to effectively navigate their environment, work with others, perform well and achieve their goals. Though soft skills are increasingly seen to benefit youth in all domains of life, these skills are poorly understood, not well assessed, and too often overlooked in policy and institutional contexts, including education, training and the workplace ${ }^{[3]}$.Employability skills focus on the personal, social and transferable skills seen as relevant to all jobs, as opposed to job-specific technical skills or qualifications. The acquisition of employability skills may be seen as a necessary first step in path towards long-term employment. Soft skills can be seen as steppingstones towards securing paid employment ${ }^{[9]}$. To ensure that the scale genuinely assess the desired employability skills or attributes in a consistent and replicable way, the scales validity and reliability need to be evaluated ${ }^{[9]}$. Using skills assessment test helps companies ensure that their jobcandidates, as well as their current employees, have the required skills to successfully perform their jobs ${ }^{[10]}$.It is assumed that our findings pertaining to determination of psychometric properties of the job-related skills inventory in Malaysian context can be used by employers, human resource service providers, researchers and social workers to examine the employability of workers while focusing on required job related skills as well as to design intervention programs for enhancing job-related skill among unemployed population.

\section{Method Respondents:}

The respondents were 102 employers from the various government department in Kota Kinabalu, Sabah Malaysia. The respondents involved in the current study were sampled using a convenience sampling method. Their age ranged from 22 to 58 years old, with a mean age of 34.22 years $(\mathrm{SD}=$ 8.45). The sample consists of $49(41.2 \%)$ male and $53(44.5 \%)$ female employers and $14 \%$ did not provide their gender information. In terms of racial background, $12.6 \%$ Malay, $5.0 \%$ Chinese, $1.7 \%$ Indian, $62.2 \%$ Indigenous people of Sabah, $1.6 \%$ Indigenous people of Sarawak, and $16.8 \%$ missing information. There were $27.7 \%$ who graduated with diploma level, $47.9 \%$ with degrees level, and $24.4 \%$ did not provide their academic status information.

\section{Measures:}

The Job-Related Skills Inventory (JRSI) is a 61 items inventory th at is adapted and modified by the researchers from these three scales (1) employability skills questionnaire ${ }^{[11]}$. (2) Malaysian Graduate Employability Skills Enhancement ${ }^{[6]}$ and (3) Goldsmith's soft skills inventory [12]. The inventory is used to measure the employer's 
preferred job-related skills in their employee for their respective jobs. It consists of seven job-related skills: interpersonal (12 items); intrapersonal (8 items); computing skills (9 items); entrepreneurial skills (9 items); management skills (10 items); personal organization (8 items); and leadership skills (5 items) This is a five-point Likert scale inventory that ranging from $1=$ very unimportant to 5 = very important. The Industrial Revolution JobRelated Skills questionnaire, the questionnaire contains 39 items with a response format of a 5point Likert scale from 1 (very unimportant) to 5 (very important). It measures four elements of the Industrial Relation 4.0 job-related skills: creativity; communication; thinking skills; and collaboration. The questionnaire was designed based on the four dimensions of the 4th Industrial Revolution suggested by pas studies $[13,14,15]$.The Short Social Desirability Scale, this scale is the short version $^{[16,17]}$, This scale is the short version of the Marlowe Crowne Social Desirability Scale (MCSDS; Crowne \& Marlowe, 1960) tested by Greenwald and Satow (1976). The Short Scale contains eight items on behaviors that are subject to cultural approval and are somehow improbable of occurrence, but have the minimum of maladjustment implied [16]. Responses were given on "Yes" = 3, "Not Sure" = 2 and "No" = 1. The Respondent who scores high on this trait tends to present a favorable image of themselves by not giving an honest answer, especially on controversial or sensitive issues.

\section{Data Analysis:}

The data were analyzed using IBM SPSS Statistics 21.0. The reliability of The Job-Related Skills Inventory was assessed by examining its Cronbach's alpha, the internal consistency reliability. To test the validity of the inventory, convergent and discriminant validity were performed. The evidence for validity convergent of the inventory was tested by examining the intercorrelation between sub-aspect of the skills and correlation between the aspects and the four dimensions of Industrial Revolution job-related skills. The discriminant validity of the Inventory was determined by examining the correlation between the inventory score and the scores of the Short Social Desirability Scale. Item analysis was also conducted to test the suitability and gaugeable of the Job-Related Skills Inventory items in the Malaysian context.

\section{Results:}

Reliability Of The Job-Related Skills Inventory: The reliability of the Job-Related Skills Inventory was examined by using the method of internal consistency Cronbach's alpha with a criterion of 0.70 , indicating good reliability ${ }^{[18] .}$ The result indicated all the aspects of the inventory showed a high level of reliability. Cronbach's alpha for all the aspects of the inventory the study were range from 0.87 to 0.95 (refer Table 1 ).

Table 1. Internal Consistency Cronbach's Alpha for the Job-Related Skills Inventory:

\begin{tabular}{|l|l|l|}
\hline Dimension & $\begin{array}{l}\text { Number of } \\
\text { items }\end{array}$ & $\begin{array}{l}\text { Cronbach's } \\
\text { Alpha } \\
\text { Coefficients }\end{array}$ \\
\hline Interpersonal & 12 items & .94 \\
\hline Intrapersonal & 8 items & .91 \\
\hline Computing Skills & 9 items & .90 \\
\hline $\begin{array}{l}\text { Entrepreneurial } \\
\text { Skills }\end{array}$ & 9 items & .93 \\
\hline $\begin{array}{l}\text { Management Skills } \\
\text { Personal } \\
\text { Organization }\end{array}$ & 8 items & .95 \\
\hline Leadership & 5 items & .87 \\
\hline
\end{tabular}

ItemAnalysisof the Job-Related Skills Inventory: In this study, the item-total correlation method was used to conduct item analysis. Item total correlation serves as a criterion for initial assessment and purification. We have adopted cut-off points of 0.30as the minimum acceptable item-total correlation coefficient ${ }^{[19]}$.The result showed in Table 2 revealed that the item-total correlation coefficient for all the items of the Job-Related Skills Inventory was exceeded the recommended value of $0.30^{[19]}$. The results suggested that all the items and Ippgu'the aspects of the inventory measure the same construct.

Table 2. Item Analysis of the Job-Related Skills Inventory 


\begin{tabular}{|c|c|c|c|}
\hline Dimension & Item & $\begin{array}{l}\text { Corrected } \\
\text { Item-Total } \\
\text { Correlation }\end{array}$ & $\begin{array}{l}\text { Cronbach's } \\
\text { Alpha } \\
\text { If Item Deleted }\end{array}$ \\
\hline \multirow[t]{12}{*}{ Interpersonal } & $\mathrm{C} 1.1$ & .742 & .930 \\
\hline & C1.2 & .709 & .931 \\
\hline & C1.3 & .778 & .928 \\
\hline & C1.4 & .734 & .930 \\
\hline & C1.5 & .689 & .932 \\
\hline & C1.6 & .703 & .931 \\
\hline & C1.7 & .715 & .931 \\
\hline & C1.8 & .707 & .931 \\
\hline & C1.9 & .626 & .934 \\
\hline & C1.10 & .676 & .932 \\
\hline & C1.11 & .782 & .928 \\
\hline & $\mathrm{C} 1.12$ & .755 & .929 \\
\hline \multirow[t]{8}{*}{ Intrapersonal } & $\mathrm{C} 2.1$ & .750 & .900 \\
\hline & $\mathrm{C} 2.2$ & .704 & .903 \\
\hline & $\mathrm{C} 2.3$ & .677 & .906 \\
\hline & $\mathrm{C} 2.4$ & .779 & .896 \\
\hline & $\mathrm{C} 2.5$ & .670 & .906 \\
\hline & $\mathrm{C} 2.6$ & .712 & .904 \\
\hline & $\mathrm{C} 2.7$ & .745 & .899 \\
\hline & $\mathrm{C} 2.8$ & .719 & .902 \\
\hline \multirow[t]{9}{*}{ Computing Skills } & C3.1 & .706 & .879 \\
\hline & C3.2 & .747 & .877 \\
\hline & C3.3 & .664 & .882 \\
\hline & C3.4 & .665 & .882 \\
\hline & C3.5 & 619 & .887 \\
\hline & C3.6 & .667 & .882 \\
\hline & C3.7 & .695 & .881 \\
\hline & C3.8 & .603 & .887 \\
\hline & C3.9 & .570 & .890 \\
\hline \multirow{9}{*}{$\begin{array}{l}\text { Entrepreneurial } \\
\text { Skills }\end{array}$} & $\mathrm{C} 4.1$ & .805 & .922 \\
\hline & C4.2 & .795 & .923 \\
\hline & C4.3 & .866 & .918 \\
\hline & C4.4 & .666 & .930 \\
\hline & C4.5 & .848 & .919 \\
\hline & C4.6 & .746 & .926 \\
\hline & C4.7 & .737 & .926 \\
\hline & C4.8 & .707 & .928 \\
\hline & C4.9 & .601 & .934 \\
\hline \multirow{10}{*}{$\begin{array}{l}\text { Management } \\
\text { Skills }\end{array}$} & C5.1 & .846 & .937 \\
\hline & C5.2 & .801 & .939 \\
\hline & C5.3 & .760 & .941 \\
\hline & C5.4 & .696 & .943 \\
\hline & C5.5 & .815 & .938 \\
\hline & C5.6 & .852 & .936 \\
\hline & C5.7 & .751 & .941 \\
\hline & C5.8 & .808 & .939 \\
\hline & C5.9 & .670 & .946 \\
\hline & C5.10 & .771 & .940 \\
\hline \multirow[t]{5}{*}{ Leadership } & C7.1 & .753 & .829 \\
\hline & C7.2 & .773 & .822 \\
\hline & C7.3 & .662 & .848 \\
\hline & C7.4 & .779 & .818 \\
\hline & C7.5 & .549 & .883 \\
\hline \multirow{8}{*}{$\begin{array}{l}\text { Personal } \\
\text { Organization }\end{array}$} & C6.1 & .772 & .896 \\
\hline & C6.2 & .708 & .901 \\
\hline & C6.3 & .708 & .901 \\
\hline & C6.4 & .613 & .911 \\
\hline & C6.5 & .835 & .892 \\
\hline & C6.6 & .814 & .892 \\
\hline & C6.7 & .708 & .901 \\
\hline & C6.8 & .612 & .910 \\
\hline
\end{tabular}

Convergent Validity of the Job-Related Skills Inventory

The convergent validity of the Job-Related Skills Inventory was assessed by examining the relationship among the aspects of the inventory and the relationship between the inventory and the four dimensions of Industrial Revolution job-related skills. We hypothesized that the correlation would be strongly and positively. This hypothesis is based on the aforementioned premise that these aspects measure the same construct - job-related skills. The result showed all the aspects of the inventory were strongly and positively correlated (correlation coefficient ranged from .47 to .87). This inventory also strongly and positively correlated with the four dimensions of the Fourth Industrial Revolution jobrelated skills (correlation coefficient ranged from .58 to .83). These results provided convergent validity evidence of the Job-Related Skills Inventory (refer to Table 3).

\section{Discriminant Validity of the Malaysian version of the Job-Related Skills Inventory:}

The discriminant validity of the Job-Related Skills Inventory was tested by examining the relationship between the seven aspects of the inventory and the scores of the Short Social Desirability Scale, we expected a modest or lower association between dimensions of these two instruments as compared to the relationship among the aspects of the inventory. As shown in Table 3, all the aspects of the inventory correlated weakly and negatively with the Short Social Desirability Scale. The correlation between the seven aspects of the inventory with the Short Social Desirability Scale ranged from $r=-.08$ to -.19 . The results suggested the good discriminant validity of the Job-Related Skills Inventory.

\section{Discussion:}

Job related skills and competencies can be considered as one of the valuable assets of any society in general and working environment in particular. Knowledge, understanding and appropriate usage of these skills can increase productivity in any organization, help with economic growth of the society, and enhance psychological well-being of both the employer and employee. However, there is a lack of there is a lack of agreement among researchers about what type of factors should be considered important while assessing employability ${ }^{[20]}$ Therefore, developing the instruments that can help with 
measurement of job-related skills in different cultural and social context and exploring the psychometric properties of these instrument seems essential for enhancing organizational productivity. Thus, the main objectives of the present study were

(1) to test the internal consistency of the inventory,

(2) to conduct item analysis

\begin{tabular}{|c|c|c|c|c|c|c|c|c|c|c|c|}
\hline Scale & $\begin{array}{l}\text { Interperso } \\
\text { nal }\end{array}$ & $\begin{array}{l}\text { Intraperso } \\
\text { nal }\end{array}$ & $\begin{array}{l}\text { Comput } \\
\text { ing } \\
\text { skills }\end{array}$ & $\begin{array}{l}\text { Entre } \\
\text { prene } \\
\text { urial } \\
\text { skills }\end{array}$ & $\begin{array}{l}\text { Man } \\
\text { age } \\
\text { men } \\
\mathrm{t} \\
\text { skill } \\
\mathrm{s}\end{array}$ & $\begin{array}{l}\text { Personal } \\
\text { Organiza } \\
\text { tion }\end{array}$ & $\begin{array}{l}\text { Lea } \\
\text { ders } \\
\text { hip }\end{array}$ & $\begin{array}{l}\text { Creativ } \\
\text { ity }\end{array}$ & $\begin{array}{l}\text { Com } \\
\text { munic } \\
\text { ation }\end{array}$ & $\begin{array}{l}\text { Thi } \\
\text { nkin } \\
\text { g } \\
\text { skill } \\
\text { s }\end{array}$ & $\begin{array}{l}\text { Colla } \\
\text { borati } \\
\text { on }\end{array}$ \\
\hline Interpersonal & & & & & & & & & & & \\
\hline Intrapersonal & $.770^{* * *}$ & & & & & & & & & & \\
\hline $\begin{array}{l}\text { Computing } \\
\text { skills }\end{array}$ & $.640^{* *}$ & $.593^{* *}$ & & & & & & & & & \\
\hline $\begin{array}{l}\text { Entrepreneuri } \\
\text { al skills }\end{array}$ & $.475^{* *}$ & $.498^{* *}$ & $.604^{* *}$ & & & & & & & & \\
\hline $\begin{array}{l}\text { Management } \\
\text { skills }\end{array}$ & $.748^{* *}$ & $.738^{* * *}$ & $.632^{* *}$ & $.612^{*}$ & & & & & & & \\
\hline $\begin{array}{l}\text { Personal } \\
\text { Organization }\end{array}$ & $.755^{* *}$ & $.791^{* *}$ & $.596^{* *}$ & $.523^{*}$ & $\begin{array}{l}.868 \\
* *\end{array}$ & & & & & & \\
\hline Leadership & $.712^{* *}$ & $.711^{* *}$ & $.585^{* *}$ & $.601^{*}$ & .845 & $.830^{* *}$ & & & & & \\
\hline Creativity & $.667^{* * *}$ & $.701^{* *}$ & $.584^{* *}$ & $.622^{*}$ & .788 & $.793^{* *}$ & .784 & & & & \\
\hline $\begin{array}{l}\text { Communicati } \\
\text { on }\end{array}$ & $.726^{* *}$ & $.663^{* *}$ & $.705^{* *}$ & $.598^{*}$ & .792 & $.769^{* *}$ & .768 & $.793^{* *}$ & & & \\
\hline $\begin{array}{l}\text { Thinking } \\
\text { skills }\end{array}$ & $.699^{* *}$ & $.727^{* *}$ & $.672^{* *}$ & $.578^{*}$ & .825 & $.786^{* *}$ & .771 & $.781^{* *}$ & $.826^{* *}$ & & \\
\hline Collaboration & $.647^{* * *}$ & $.689^{* *}$ & $.633^{* *}$ & $.531^{*}$ & .792 & $.706^{* *}$ & $\begin{array}{l}.752 \\
* *\end{array}$ & $.781^{* *}$ & $.786^{* *}$ & .819 & \\
\hline $\begin{array}{l}\text { Social } \\
\text { desirability }\end{array}$ & -.161 & -.189 & -.150 & -.079 & $\begin{array}{l}- \\
.126\end{array}$ & -.100 & $\begin{array}{l}- \\
.084\end{array}$ & -.055 & -.152 & $\begin{array}{l}- \\
.166\end{array}$ & $\begin{array}{l}- \\
.289^{* * *}\end{array}$ \\
\hline
\end{tabular}

Correlation is significant at the 0.01 level (2-tailed). 
(4) to measure discriminant validity of the JobRelated Skills Inventory in the Malaysian context. Job-Related Skill Inventory has seven dimensions measuring different skills. These skills are (a) interpersonal, (b) intrapersonal, (c)computing skills, (d) entrepreneurial skills, (e) management skills, (f) personal organization and (g) leadership.With respect to our first objective, which was focused on testing the internal consistency of the Job-Related Skills inventory in the Malaysian context it was found that the instrument has good internal consistency as Cronbach's alpha for all the dimensions of the inventory were ranging from 0.87 to 0.95 . Interpretation about the level of internal consistency for Job related Skill Inventory achieved from present study ${ }^{[21]}$ as according to them while evaluating Cronbach's alpha of a scale ,the value of 0.9 is considered excellent, while the value $0.9-0.8$ is considered good and the values of $0.8-0.7$ could be considered as acceptable. Scales to measure job related skills has been developed and validated with various populations and cultures across the globe. Another study ${ }^{[22]}$, while developing and validating Employability Appraisal Scale (EAS), a 35 items scale in 5 point Likert type scale (ranging from "Strongly disagree"-1 to "Strongly agree"-5) with Spanish Sample found out that the scale and subscales has Cronbach alpha values ranging from 0.67 to 0.87 , which are considered above the recommended level.As for the second objective in relation to conduct item analysis of the Job-Related Skills Inventory in the Malaysian context it was found that the item-total correlation coefficient for all the items of the Job-Related Skills Inventory was exceeded the recommended value of 0.30 ; thus it could be concluded that all the items and the aspects of the inventory measure the same construct. Past study ${ }^{[22]}$, while measuring the reliability of Employability Appraisal Scale (EAS) with Spanish Sample also found out strong correlation between the items. With respect to our third objective which was focused on the measurement of convergent validity of the Job-Related Skills Inventory in the Malaysian context, the results showed that the inventory has good convergent validity as the strong and positive relationship among all the dimension of the inventory (correlation coefficient ranged from .47 to .87) and the relationship between the inventory and the four dimensions of Industrial Revolution job-related skills(correlation coefficient ranged from .58 to .83) was found. While usage of inventories to determine job-related skills seems effective way to enhance productivity, one of the problems is faking, response distortion or giving socially desirable responses while answering these inventories which may negatively affect the results by reducing validity of the instruments. Thus, our fourth objective discussed the discriminant validity of the Job-Related Skills Inventory in the Malaysian context by using the Short social desirability scale. Based on the finding, it could be assumed that the inventory has good discriminant validity as all the dimensions of the inventory correlated weakly and negatively (ranging from $\mathrm{r}=-.08$ to -.19 ) with the Short Social Desirability Scale. Our findings that weak and negative correlation exist between social desirability leading to response distortion while responding to Job-related skill inventory are supported by past study ${ }^{[23]}$ that in job selection process, individuals do not engage much in response distortion.Our findings suggest thatJobrelated skill inventory which was found to be a reliable and valid measure focusing on employability skills such as interpersonal, intrapersonal, computing skills, entrepreneurial skills, management skills, personal organization and leadership has both personal and social dimensions that are relevant to all jobs. Thus, measurement and acquisition of these skills could be considered as an important step towards long-term employment.

\section{Conclusion:}

In nowadays world, if getting a good job depends a lot on hard skills such as education and training, job related soft skills are required to maintain the job and achieve professional fulfilment. Awareness and effective use of Job-related skills, capabilities, or dimensions can help workers perform up to their maximum potential in an organizational set up which in return can have positive impact on productivity and overall development of a country. The present study was aimed to explore psychometric properties of Job-Related Skills inventory which comprised of interpersonal and intrapersonal skills, computing skills, entrepreneurial skills, management skills, personal organization and leadership. It was found that this inventory is a reliable and valid tool which could be used in various organizations in the Malaysian context.

\section{Acknowledgement:}

A special thank you to the Ministry of Higher Education for the research grant (FRGS0492/2018) as well as the Centre for Research and Innovation of University Malaysia Sabah. We also thank you to all participants for their participation and time. 


\section{References:}

[1] Chung, R.F., Ching, Y., Cheok, C.K., \& Hill, C.(2015). Employability of graduates in Malaysia: The perception of selected students and parents, Retrieved from https://www.britishcouncil.org/sites/default/files/ phase_ii_employability_of_graduates_in_malays ia student parent perceptio.pdf

[2] Lim, Y. M., Cham, T. H., Lee, T. H. \& Ramalingam, C. L. (2019). Employer-Employee Perceptual Differences in Job Competency: A Study of Generic Skills, Knowledge required, and Personal Qualities for Accounting-Related Entry-Level Job Positions, internationaljournal of Academic Research in Accounting, Finance and Management Sciences 9(4), 73-8

[3] Ignatowski, C.(2017). What works in soft skills development for youth employment? A donors' perspective, Youth Employment Funders Group \& Mastercard Foundation

[4] Lim, J.(October 11. 2019).Malaysia 2020 unemployment rate seen at $3.3 \%$, The Edge Markets, Retrieved from https://www.theedgemarkets.com/article/malaysi a-2020-unemployment-rate-seen-33

[5] Plecher, H.(2020). Unemployment rate in Malaysia 2019, Statistia, Retrieved from https://www.statista.com/statistics/319019/unem ployment-rate-in-malaysia/

[6] Abdul Hamid,M.S., Islam, R., \& Noor Hazilah, A.M.(2014).Malaysian graduates' employability skills enhancement: An application of the importance performance analysis, Journal Global Business Advancement, 7,3,181-197

[7] Central Bank of Malaysia Survey (2002), retrieved from http://bond.npc.org.my

[8] World employment and social outlook:Trends for Youth.(2016).International Labour Office, Geneva, URL: https://www.ilo.org/global/research/globalreports/weso/2016/WCMS 513739/lang-en/index.htm

[9] Blades, R., Fauth, B., and Gib, J.(2012).Measuring Employability Skills. A rapid review to inform development of tools for project evaluation, National Children's Bureau: working with children, for children

[10] Zojeeska, A.(2019).Everything You Need to Know About Skill Assessment Tests, Retrieved from

https://www.talentlyft.com/en/blog/article/278/e verything-you-need-to-know-about-skillassessment-tests

[11] Singh \& singhsingh, G. K.G., \& Singh, S. K. G. (2008). Malaysian graduates' employability skills. Unitar e-Journal, 4(1), 15-45.

[12] Chamorow Chamorro-Premuzic, T, Arteche, A., Bremner, A.J., Greven, C., \& Furnham, A.(2010). Soft skills in highereducation: importance and improvement ratings as a function of individual differences and academic performance, Educational Psychology,30,(2), 221-241 DOI: $10.1080 / 01443410903560278$

[13]bekthesibektheshi, E.(2017). The 'Four Cs' Collaboration, communication, critical thinking and creativity at the faculty of Arts (FLUP), University of Porto, Portugal, The Journl of International Social Research,50(10), 56- 62.

[14] Lamb \&Doeche.(2017).Lamb,S.,\&Doecke, Q.M.(2017).Key skills for the $21^{\text {st }}$ century:An evidence-based review, Future Frontiers Analytical Report, New South Wales State of New South Wales (Department of Education), Retrieved from https://pdfs.semanticscholar.org/723e/c36a531 227a534d2cec629487bbc3d1ca428.pdf

[15] Guo, Z.(2016). The Cultivation of 4C's in China-Critical Thinking, Communication, Collaboration and Creativity, International Conference on Education, Management and Applied Social Science

[16] Crowne,D.P.,\&Marlowe,D.(1960).A new scale of social desirability independent of Psychopathology, Journal of Consulting Psychology,24,4,349354.doi: $10.1037 /$ hoo 47358

[17] Greenwald.H.J., \&Satow. Y.(1970). A short social desirability scale. Psychological Reports, 27, 131-135 
[18]Kock, N. (2017). Which is the best way to measure job performance: Self-perceptions or official supervisor evaluations? International Journal of e-Collaboration, 13(2), 1-9.

[19\} Cristobal, E., Flavián, C., \&Guinalíu, M.(2007).Perceived e-service quality (pesq): Measurement validation and

Effects on consumer satisfaction and web site loyalty. Managing Service Quality: An International Journal,17(3), 317-340. Doi:10.1108/09604520710744326

[20] Tymon A. (2013). The student perspective on Employability. Stud. High. Educ. 38, 841-856. 10.1080/03075079.2011.604408
[21] George, D., \& Mallery, P. (2003). SPSS for Windows step by step: A Simple Guide and Reference. 11.0 Update (4th ed.). Boston: Allyn \& Bacon.

[22] Llinares-Insa, L. I., González-Navarro, P., Zacarés-González, J. J., \& Córdoba-Iñesta, A. I. (2018). Employability Appraisal Scale (EAS): Development and Validation in a Spanish Sample. Frontiers in psychology, 9, 1437. Https://doi.org/10.3389/fpsyg.2018.01437

[23] Ellingson, J. E., Sackett, P. R., \& Connelly, B. S. (2007). Personality assessment across selection and development contexts: Insights into response distortion. Journal of Applied Psychology, 92(2), 386395. Https://doi.org/10.1037/0021-9010.92.2.386 